University of Nebraska - Lincoln

DigitalCommons@University of Nebraska - Lincoln

2001

\title{
Monthly fractional green vegetation cover associated with land cover classes of the conterminous USA
}

\author{
Kevin P. Gallo \\ National Climatic Data Center, Kevin.P.Gallo@noaa.gov \\ Dan Tarpley \\ NOAA/NESDIS \\ Ken Mitchell \\ NOAA/NCEP \\ Ivan Csiszar \\ CIRA
}

Timothy Owen

NOAA/NESDIS

See next page for additional authors

Follow this and additional works at: https://digitalcommons.unl.edu/natrespapers

Part of the Natural Resources and Conservation Commons

Gallo, Kevin P.; Tarpley, Dan; Mitchell, Ken; Csiszar, Ivan; Owen, Timothy; and Reed, Brad, "Monthly fractional green vegetation cover associated with land cover classes of the conterminous USA" (2001). Papers in Natural Resources. 188.

https://digitalcommons.unl.edu/natrespapers/188

This Article is brought to you for free and open access by the Natural Resources, School of at DigitalCommons@University of Nebraska - Lincoln. It has been accepted for inclusion in Papers in Natural Resources by an authorized administrator of DigitalCommons@University of Nebraska - Lincoln. 


\section{Authors}

Kevin P. Gallo, Dan Tarpley, Ken Mitchell, Ivan Csiszar, Timothy Owen, and Brad Reed 


\title{
Monthly fractional green vegetation cover associated with land cover classes of the conterminous USA
}

\author{
Kevin Gallo, ${ }^{1}$ Dan Tarpley, ${ }^{2}$ Ken Mitchell, ${ }^{3}$ Ivan Csiszar, ${ }^{4}$ Timothy Owen, ${ }^{5}$ and Brad Reed ${ }^{6}$
}

\begin{abstract}
The land cover classes developed under the coordination of the International Geosphere-Biosphere Programme Data and Information System (IGBP-DIS) have been analyzed for a study area that includes the Conterminous United States and portions of Mexico and Canada. The 1-km resolution data have been analyzed to produce a gridded data set that includes within each $20-\mathrm{km}$ grid cell: 1) the three most dominant land cover classes, 2) the fractional area associated with each of the three dominant classes, and 3) the fractional area covered by water. Additionally, the monthly fraction of green vegetation cover (fgreen) associated with each of the three dominant land cover classes per grid cell was derived from a 5 year climatology of $1-\mathrm{km}$ resolution NOAA-AVHRR data. The variables derived in this study provide a potential improvement over the use of monthly fgreen linked to a single land cover class per model grid cell.
\end{abstract}

\section{Introduction}

The land surface variables in the land surface model component of the coupled Eta model include vegetation (land cover) type and fractional green vegetation cover (fgreen) [Chen et al., 1996; Betts et al., 1997; Mitchell et al., 2000]. Fgreen is defined as the fraction of horizontal area associated with the photosynthetically active green vegetation that occupies a model grid cell. In representation of the presence of green vegetation over the land surface some models utilize a constant fgreen value and vary the leaf area index (LAI) throughout the growing season [Zeng et al., 2000]. Fgreen, as used by the National Centers for Environmental Prediction (NCEP) in the land surface model component in the Eta model, is varied through the growing season while a constant value of LAI is utilized. The introduction of improved satellite-derived monthly values of fgreen into the Eta model resulted in improved model forecasts of land-surface fluxes and planetary boundary layer structure [Betts et al., 1997].

Due in part to lack of availability of high resolution data sets, the current land cover class (after Dorman and Sellers, [1989]) and fgreen [Gutman and Ignatov, 1998] variables used in the Eta analysis are represented in the model as one (most dominant) land cover class per grid cell with monthly fgreen

\footnotetext{
${ }^{1}$ NOAA/NESDIS, EROS Data Center, Sioux Falls, SD

${ }^{2}$ NOAA/NESDIS, Camp Springs, MD

${ }^{3}$ NOAA/NCEP, Camp Springs, MD

${ }^{4}$ CIRA, Camp Springs, MD

${ }^{5} \mathrm{NOAA} / \mathrm{NESDIS}$, National Climatic Data Center, Asheville, NC

${ }^{6}$ Raytheon, EROS Data Center, Sioux Falls ,SD
}

Copyright 2001 by the American Geophysical Union.

Paper number 2000 GL011874. 0094-8276/01/2000GL011874\$05.00 values derived as an average for the grid cell. The advantages of sub-grid cell vegetation information have been discussed by Koster and Suarez [1992] and demonstrated by Avissar and Pielke [1989] as well as others. The objectives of this study included development of land surface data sets for use in coupled land-atmosphere models that include sub-grid cell land classes and the seasonal characteristics of vegetation (fgreen) associated with each of those land classes for the Conterminous USA. A grid cell size of $20 \mathrm{~km}$ by $20 \mathrm{~km}$ was selected for this initial analysis as this is the nominal grid cell size in the current operational Eta model at NCEP

\section{Methodology}

\subsection{Dominant Land Cover Classes}

The land cover information for this study was extracted from the IGBP-DIS $1 \mathrm{~km}$ land cover data set [Loveland and Belward, 1997] that was produced to make available a global data set with high spatial resolution and known accuracy. The data were reprojected from the original Interrupted Goode Homolosine map projection to a Lambert Azimuthal Equal Area map projection.

The 17 IGBP classes were condensed into 14 classes (CIGBP) by combining several of the classes (Table 1). The classes were combined due to a concern that a grid cell comprised of many of the more specific classes (e.g., 10\% aerial coverage of each of the five forest classes) and a single general class (e.g., $30 \%$ aerial coverage of grasslands) would be defined as predominantly grassland although a generic forest class (with

Table 1. Current IGBP and Condensed IGBP (CIGBP) classes.

IGBP Condensed IGBP
1. Evergreen Needleleaf Forest
2. Evergreen Broadleaf Forest
0. Water Bodies/No class values
3. Deciduous Needleleaf Forest
1. Forests
4. Deciduous Broadleaf Forest
5. Mixed Forest
2. Evergreen Broadleaf Forest
6. Closed Shrublands
7. Open Shrublands
8. Woody Savannas
9. Savannas
10. Grasslands
11. Permanent Wetlands
12. Croplands
13. Urban and Build-Up
3. Deciduous Needleleaf Forest
6. Closed Shrublands
7. Open Shrublands
8. Woody Savannas
9. Savannas
10. Grassland
11. Permanent Wetlands
12. Cropland/Natl. Vegt. Mosaic
13. Urban and Build-Up
15. Snow and Ice
14. Cropland/Natl. Vegt. Mosaic 16. Barren or Sparsely Vegt.
15. Snow and Ice
16. Barren or Sparsely Vegt.
17. Water Bodies 
$50 \%$ aerial coverage) realistically could be defined as the predominant class. IGBP classes 4 (Deciduous Broadleaf Forest) and 5 (Mixed Forest) were combined with class 1 (Evergreen Needleleaf Forest). Additionally class 14 (Cropland/Natural Vegetation Mosaic) was combined with class 12 (Croplands). The combined classes displayed similar seasonal characteristics in a subjective analysis of an annual time series of the normalized difference vegetation index at monthly intervals over the Conterminous USA. Comparisons within specific regions indicated greater similarity.

The number of CIGBP classes, excluding water bodies, were determined for each 20 by $20 \mathrm{~km}$ grid cell in the study area. The proportion of the grid cell area occupied by each of the classes, and by water bodies, was determined and evaluated to provide recommendations for the number of classes required to adequately represent the land cover of the grid cells.

\subsection{Development of Fractional Green Vegetation Cover}

The fraction of green vegetation per grid cell (fgreen, Equation 1),

$$
\text { fgreen }=\left(N D V I-N I_{0}\right) /\left(N_{D V I}-N_{1} D_{0}\right)
$$

as described by Gutman and Ignatov [1998], and demonstrated useful in coupled land-atmosphere models [Betts et al., 1997 ], requires maximum and minimum thresholds of the normalized difference vegetation index (NDVI). Selection of the maximum $\left(\mathrm{NDVI}_{1}\right)$ and minimum $\left(\mathrm{NDVI}_{0}\right)$ thresholds of NDVI required for computation of fgreen was based on NDVI values of the biweekly Conterminous USA 1-km AVHRR data set [Eidenshink, 1992] in combination with the CIGBP land cover classes.

An interpolated mid-month NDVI data set was prepared from the biweekly Conterminous USA data set. All biweekly data available from 1993 and 1995 through 1998 were interpolated on a daily basis and temporally processed to remove fluctuations in the NDVI signal due to cloud or other contamination [Swets, et al., 1999]. The mid-month NDVI value was retained from the interpolated daily values. Data of 1994 were excluded from the analysis due to low solar elevation angles associated with the AVHRR data acquisitions during this year.

Computation of $\mathrm{NDVI}_{1}$ included analysis of the maximum mid-month NDVI values observed in each of the 5 years (1993, 1995-1998) for those CIGBP land cover classes $(1,2,6,8,9$, 10 , and 12; Table 1) that represent potentially dense vegetation. Frequency distributions of the maximum annual NDVI values were computed for each CIGBP class on a yearly basis. The NDVI value associated with a cumulative frequency distribution value of $98 \%$ (similar to Sellers et al., [1996]) was selected as the maximum NDVI threshold for that year. Yearly maximum NDVI threshold values for the CIGBP Forests class ranged from 0.70 in 1993 to 0.73 in 1997 and 1998. Computation of the $\mathrm{NDVI}_{\mathrm{i}}$ values for each land cover class was based on the 5-year average of the yearly maximum NDVI threshold values. Mean NDVI, values ranged from 0.61 for the Grasslands class to 0.72 for the Forests class. The overall NDVI value of 0.69 was computed as the weighted (by area associated with the land cover classes) mean of the $\mathrm{NDVI}_{1}$ values computed for each of the above land cover classes.

Computation of $\mathrm{NDVI}_{0}$ was more restrictive than computation of $\mathrm{NDVI}_{1}$ as the goal was to derive a value that represents the bare soil or non-green (i.e., not transpiring) vegetation. The derivation of $\mathrm{NDVI}_{0}$ was based on an analysis of the 5-year avearage NDVI values for the month of January. Additionally, the analysis was restricted to the North Central portion of the conterminous USA ( 40 to $45^{\circ} \mathrm{N}, 89$ to $105^{\circ} \mathrm{W}$ ) that is primarily Croplands or Grasslands. Forest classes located in this region were excluded from the analysis, thus the Croplands or Grasslands cover types dominated ( $>95 \%)$ the region. The land cover associated with these classes, in this region during the month of January, should exhibit either non-green vegetation, bare soil, or snow.

The visible and near-IR data used to compute the NDVI were examined to identify areas within this region with, and without, snow cover. NDVI values associated with the cumulative frequency distribution value of $5 \%$ (as suggested by Sellers et al., [1996]) appeared to be associated with areas of snow cover. The NDVI values obtained from bare soil or non-green vegetation appeared to be associated with the NDVI values at a cumulative frequency distribution value of $50 \%$. Thus, the NDVI values observed at the $50 \%$ cumulative frequency leve] were selected as the $\mathrm{NDVI}_{0}$ values. The $\mathrm{NDVI}_{0}$ threshold for the Cropland CIGBP class was 0.08 . $\mathrm{NDVI}_{\mathrm{o}}$ values ranged from 0.07 for the Closed Shrubland class to 0.12 for the Grasslands class located in the region. The overall $\mathrm{NDVI}_{0}$ value of 0.09 was computed as the weighted (by area associated with the land cover classes) mean of the $\mathrm{NDVI}_{0}$ values computed for each of these land cover classes.

The mid-month NDVI values were averaged on a monthly basis over the 5 available years of data. Monthly values of fgreen were computed [equation 1] from the 5-year monthly NDVI values with $\mathrm{NDVI}_{0}=0.09$ and $\mathrm{NDVI}_{1}=0.69$. When observed NDVI values were less than 0.09 fgreen was assigned a value of 0.0 , and when observed values were greater than 0.69 fgreen was assigned a value of 1.0 .

\section{Results}

The mean number of classes per grid cell was between 2 and 3 (2.8). A maximum of nine CIGBP classes (excluding water) were found in six grid cells, while over 3800 of the 25,806 grid cells included only a single class. When analyzed on an areal basis, more than $90 \%$ of the grid cells had more than $98 \%$ of their land area identified by three or less CIGBP classes. Thus, the three most dominant CIGBP classes per grid cell were selected to represent the land cover of each grid cell. The most dominant land cover class per grid cell is displayed in Figure 1.

One of the motivating factors for development of sub-grid cell information was the recognition that within vegetation cover transition zones a single land cover class per grid cell will likely misrepresent the surface conditions within the grid cell. Six grid cells that lie on an east-west transect from Eastern Arkansas through Tulsa, Oklahoma, to Western Oklahoma were intensively examined (Figure 1). This region represents a gradient of annual precipitation from over $127 \mathrm{~cm}$ for the eastern grid cell to less than $70 \mathrm{~cm}$ for the western grid cell. The crops associated with the Croplands dominated grid cells varied from cotton and rice (east) to wheat (west) [USDA, 1994]. The fgreen values were examined for the three most dominant land covers of each grid cell. Some grid cells (1C, 1D, 1F) displayed similar trends in fgreen for the three land covers, while trends within the other grid cells differed (1A, 1B, 1E).

The Forests within the easternmost grid cell (Figure 1E) comprised $14 \%$ of the non-water area within the grid cell. The Forests reached their maximum values of fgreen sooner in the spring than the Croplands (79\% of area) or Savannas (5\% of 

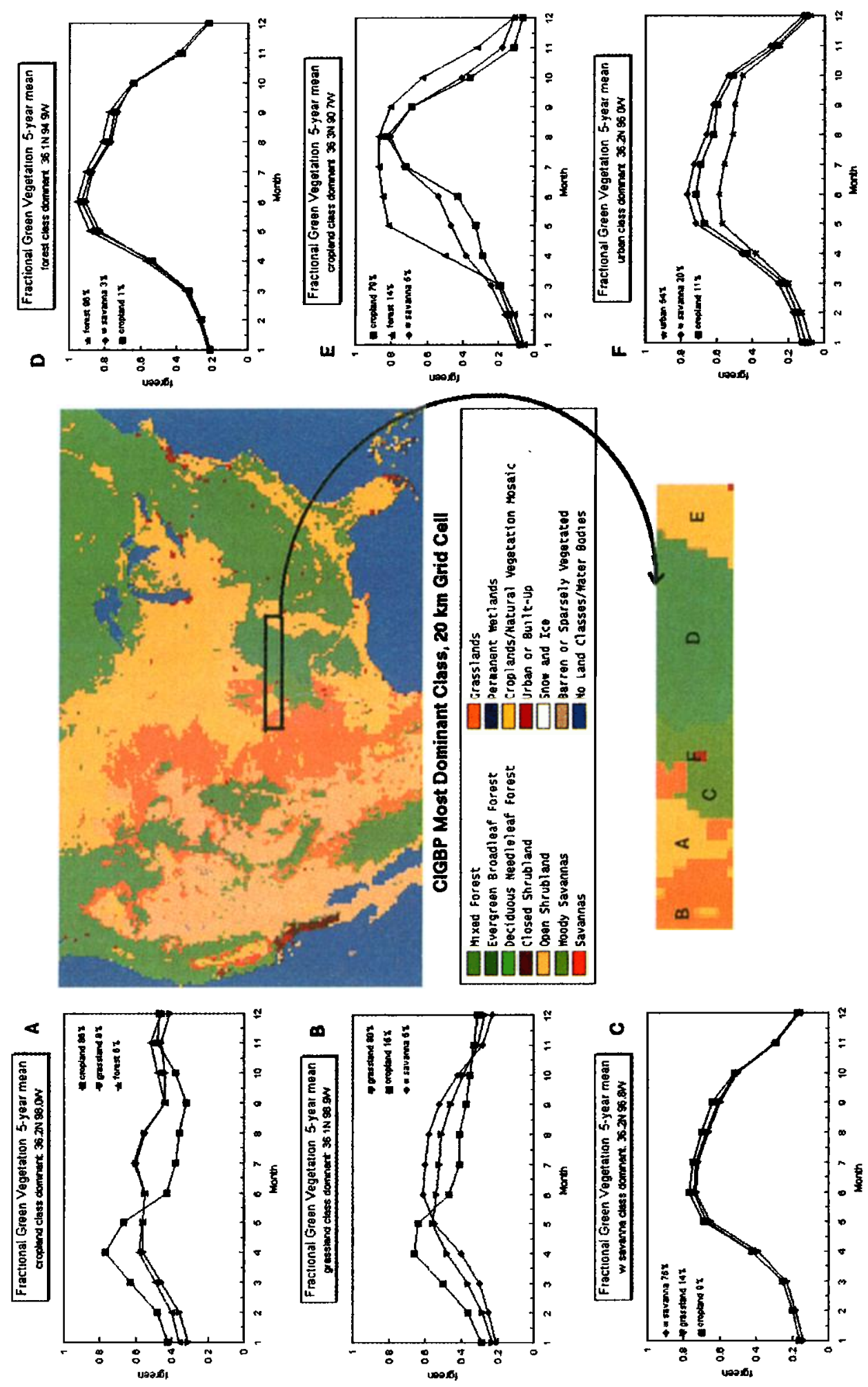

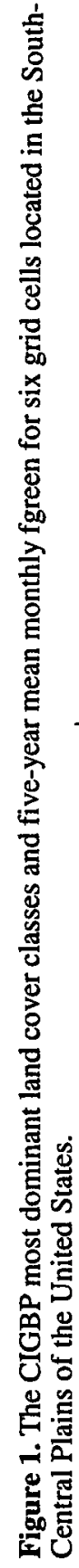


area) class values. The Forests fgreen values were greater than 0.80 from May through September while the Croplands fgreen was above 0.80 only during August.

The Urban, Woody Savannas and Croplands classes all displayed similar trends for fgreen in the Urban dominated $(54 \%$ of area) grid cell (Figure 1F), although the Urban class displayed the lowest values. The fgreen values of the Urban class were never greater than 0.60 while the fgreen values of both of the other classes reached over 0.70 .

The western, Croplands dominated ( $86 \%$ of area), grid cell (Figure 1A) displayed two distinct trends for the fgreen values. The Croplands signal was characteristic of wheat, which achieves maximum fgreen values during the spring months. The Grasslands and Forests classes displayed similar trends in fgreen with lower fgreen values than the Croplands during the spring months and greater values during the summer.

The overall impact of the use of three land cover classes and their associated monthly fgreen values was assessed for the entire study area (Figure 1). A significant difference in fgreen, defined as a difference greater than $0.1(10 \%)$, between any of the land cover classes within a grid cell, was assessed for each grid cell on a monthly basis. Significant differences in fgreen were observed for over $57 \%$ of the non-water grid cells in the study area during at least one month. Over $6 \%$ of the grid cells exhibited significant differences in fgreen during all 12 months.

\section{Conclusions}

The results suggest that for the CIGBP land cover classes, at a $20 \mathrm{~km}$ grid cell size, three land cover classes are sufficient to represent the land cover within a grid cell. The results also suggest that differences in fgreen between the classes within a grid cell are sufficient to warrant derivation of fgreen for each of the three land cover classes within a grid cell.

From the information available in this data set a single areal weighted fgreen can be computed for each grid cell as the sum of the fgreen for each of the three most dominant cover types (and water) weighted by the proportional area occupied by the cover types within the grid cell. Based on the results of this study, the area occupied by any other cover types within a grid cell can be considered negligible. Water should be assigned a minimal fgreen value of 0.001 for this computation.

\section{Acknowledgements}

This study was partially supported by the NOAA/NASA Joint GEWEX/GCIP Research Program and the NASA Land Surface Hydrology program. The data sets included in this study are available on CD-ROM from the lead author upon request.

\section{References}

Avissar, R. and R.A. Pielke, A Parameterization of Heterogeneous Land Surfaces for Atmospheric Numerical Models and Its Impact on Regional Meteorology, Mon. Wea. Rev. vol. 117, pp. 2113-2136, 1989.

Betts, A., F. Chen, K. Mitchell, and Z. Janji, Assessment of Land surface and boundary layer models in two operational versions of the NCEP Eta model using FIFE data, Mon. Wea. Rev. vol. 125, pp. 2896-2915, 1997.

Chen, F., K. Mitchell, J. Schaake, Y. Xue, H. Pan, V. Koren, Q.Y. Duan, M. Ek, and A. Betts, Modeling of land surface evaporation by four schemes and comparison with FIFE observations, J. Geophys. Research vol. 101, pp. 7251-7268, 1996.

Dorman, J.L., and F.J. Sellers, A Global Climatology of Albedo, Roughness Length and Stomatal Resistance for Atmospheric General Circulation Models as Represented by the Simple Biosphere Model (SiB), J. Appl. Meteorol., vol. 28, pp. 833-855, 1989.

Eidenshink, J.E., The 1990 Conterminous U.S. AVHRR Data Set. Photogram. Engr. \& Rem. Sensing. vol. 58, pp. 809-813, 1992.

Gutman, $G$. and $A$. Ignatov, Derivation of green vegetation fraction from NOAA/AVHRR for use in numerical weather prediction models. Intl. J. Remote Sensing. vol. 19, pp. 1533-1543, 1998

Koster, R.D. and M.J. Suarez, Modeling the land surface boundary in climate models as a composite of independent vegetation stands. J. Geophys. Resr. vol. 97, pp. 2697-2715, 1992.

Loveland, T.R. and A.S. Belward, The IGBP-DIS global $1 \mathrm{~km}$ land cover data set, DISCover: first results. Intl. J. Remote Sensing. vol 18, pp. 3289-3295, 1997.

Mitchell, K., Y. Lin, E. Rogers, C. Marshall, M. Ek, D. Lohmann, J. Schaake, D. Tarpely, P. Grunmann, G. Manikin, Q. Duan, and V. Koren, Recent GCIP-sponsored advancements in coupled land-surface modeling and data assimilation in the NCEP Eta mesoscale model. Preprints of $15^{\text {th }}$ Conference on Hydrology, American Meteorological Society, Boston, MA, pp. 180-183.

Sellers, P.J., S.O. Los, C.J. Tucker, C.O. Justice, D.A. Dazlich, G.J. Collatz and D.A. Randall, A revised land surface parameterization (SiB2) for atmospheric GCMs. Part II: The generation of global fields of terrestrial biophysical parameters from satellite data. J. Climate. vol. 9, pp. 706-737, 1996.

Swets, D.L., B.C. Reed, J.D. Rowland and S.E. Marko, A weighted least-squares approach to temporal NDVI smoothing. Proceedings Amr. Soc. Photogram. Rem. Sens. 17-21 May, Portland OR., ASPRS, Washington, D.C. pp. 526-536, 1999.

USDA, Major world crop areas and climatic profiles. World Agriculture Outlook Board, U.S.Department of Agriculture. Wahsington, D.C., 1994.

Zeng, X, R.E. Dickinson, A.Walker, M. Shaikh, R.S. DeFries, and J. Qi, Derivation and evaluation of global $1-\mathrm{km}$ fractional vegetation cover data for land modeling. J. Appl. Meteorol. vol.39, pp. 826-839, 2000.

K. Gallo, D. Tarpley, K. Mitchell, I. Csiszar, T. Owen, and B. Reed. E-mail: Kevin.P.Gallo@noaa.gov, Dan.Tarpley@noaa.gov, Kenneth.Mitchell@noaa.gov, Tim.Owen@noaa.gov,reed@usgs.gov icsiszar@nesdis.noaa.gov,

(Received June 13, 2000; accepted January 10, 2001.) 